\title{
THE EFFECTS OF ADDING SOY FIBER TO WHEAT SPAGHETTI
}

\begin{abstract}
This study has evaluated the effects of adding $4 \%, 6 \%$ and $8 \%$ soy fiber to wheat pasta for the production of dry wheat spaghetti. The properties of the mixture were evaluated for humidity, falling number, ashes, color, retained gluten, and subjected to farinograph (water absorption, development, stability) and extensograph analyses (resistance and extensibility). The spaghetti was evaluated with cooking tests (performance, increased volume, loss of soluble solids to cooking water) and sensory analysis. The addition of soy fiber to wheat flour resulted in mixtures with rheological and physicochemical characteristics suitable for the production of wheat spaghetti, enhancing performance and reducing the loss of soluble solids to the cooking water. The sensory analysis showed that, for all parameters tested, panelists favored mixtures with up to $6 \%$ soy fiber addition.
\end{abstract}

KEY-WORDS: SENSORY ANALYSIS; FUNCTIONAL FOOD; SOY FIBER.

* Engenheira deAlimentos, Universidade de Caxias do Sul (UCS), Caxias do Sul, RS (e-mail: alinebenedetti@ gmail.com).

** Engenheira de Alimentos, Professora, Faculdade UnB Planaltina, Planaltina, DF (e-mail: vaniars@unb. br). 


\section{INTRODUCTION}

According to the World Health Organization (WHO) and the Food and Drug Administration (FDA), pasta is a good product for the addition of nutrients (CHILLO et al., 2008b), and possesses several other positive qualities including extended shelf life and high carbohydrate content (CHILLO et al., 2008a).

Spaghetti was the first food to receive FDA authorization for the addition of vitamins and iron, in 1940 (MARCONI \& CARCEA, 2001). Since then, various studies have been conducted to evaluate the addition of fiber, proteins of plant origin, as well as vitamins and minerals to improve the nutritional value of spaghetti (BAHNASSEY \& KHAN, 1986; KNUCKLES et al., 1997).

Fibers are not digested by humans but ferment in the presence of bacteria that inhabit the colon; these bacteria produce lactic acids and break down fatty acids into short chains, thus helping reduce blood cholesterol levels. An adequate intake of fibers may help to prevent, or aid in the treatment of obesity, diabetes, colon cancer, ulcers and coronary diseases (BOSAEUS, 2004; SCHEPPACH et al., 2004). Because of the perceived benefits of fibers intake, researchers have shown great interest about them (ROSTAGNO, PALMA \& BARROSO, 2005). Soy fiber is mainly composed of carbohydrates from the cotyledon walls, without peel contamination (SEIBEL \& BELEIA, 2008).

The addition of fibers may change the rheological and physicochemical properties of flours during cooking (ROSTAGNO, PALMA \& BARROSO, 2005; BAIANO, CONTE \& DELNOBILE, 2006; CHILLO et al., 2008b).

The present study aimed to evaluate how the addition of soy fiber to a wheat flour mixture affects the behavior of wheat spaghetti.

\section{MATERIAL AND METHODS}

Soy fiber FIBRARICH FB 20 (The Solae Company) was added to a mixture of wheat flour Orquídea Especial MI (Tondo S/A) and water (40.25\%) in the following concentrations: 4\%, 6\% e $8 \%$.

Wheat flour and soy fiber mixtures were formulated and dry pasta was processed at the Tondo S/A - Unidade Forqueta (Caxias do Sul - RS/Brazil) in laboratorial scale. The ingredients that make up the dry mixture were homogenized with the help of a mixer (Extrusora Men 8 - Monte Castelo), followed by the addition of water for 10 minutes. Next, the mixture was molded in the shape of spaghetti using a trafile (Monte Castelo).

The formulations included a control (without addition of soy) and soy fiber added to the wheat mixture in different proportions.

\subsection{ANALYSIS OF THE MIXTURE OF WHEAT FLOUR AND SOY FIBER}

The following rheological and physicochemical analyses were conducted on the wheat flour added with soy mixtures:

- Humidity, determined by an Infrared Moisture Analyzer, OHAUS, MB200 (TOLEDO, 1995);

- Falling Number, method AACC n. 56-81 (AACC, 1995);

- $\quad$ Ashes method ICC n.104/1 (ICC, 1990);

- Color analysis (parameters $L^{*}, a^{*}$ ) determined by Colorimeter Minolta, model CR300s (MINOLTA, 1991);

- Retained gluten analysis by method AACC n. 38-12 (AACC, 1995); 
- Farinologic analysis (water absorption) method AACC n. 54-20 (AACC, 1995);

- Extensograph analysis (resistance and flexibility), method AACC n. 54-10 (AACC, 1995).

\subsection{SPAGHETTI ANALYSIS}

The spaghetti was evaluated with a cooking test following the method AACC (1983) n.16-50 and considered the following parameters:

\section{- Spaghetti performance}

The stickiness after cooking was evaluated using the following scale: 5 - very tender, separate; 4 - completely separate; 3 - mildly stuck together; 2 - stuck together; 1 - very stuck together; 0 - completely stuck together.

In order to ascertain whether the product was cooked, samples were taken regularly and the presence of the central thread was evaluated. The product was considered cooked (al dente) when the central thread was no longer present, a criterion adopted by the Toronto Industries S/A - Unidade Forqueta (Caxias do Sul - RS/Brazil).

\section{- Increase in volume}

The increase in volume after cooking was determined in the following manner: samples were immersed in $140 \mathrm{~mL}$ hexane; the volume of hexane displaced by either cooked or raw pasta was calculated. The results were written as a function of the number of times the pasta increased in volume.

\section{- Loss of soluble solids or residues to cooking water}

The amount of soluble solids in cooking water was determined by the evaporation of a $25 \mathrm{~mL}$ sample in a stove at $110^{\circ} \mathrm{C}$ until a constant weight was reached. The results were written as percentage of the difference between the total mass before and after water evaporated.

\subsection{SENSORY ANALYSIS}

The sensory analysis of the wheat spaghetti with added fiber was performed by untrained panelist using a profile test feature. Color, taste, chewability, firmness and elasticity of the food were rated through a 9-point hedonic scale with the following extremes: I disliked it very much (1) I liked it very much (9) (MORAIS, 1993).

\section{RESULTS AND DISCUSSION}

\subsection{ANALYSIS OF THE WHEAT FLOUR WITH SOY FIBER MIXTURE}

The addition of soy fiber did not significantly interfere with the moisture content of the formulations $(p<0.05)$ when compared to control (Table 1$)$. This result is very important because moisture content affects the activity of the alfa-amylase, an enzyme that controls viscosity through the amylolytic hydrolysis of the starch (HOSENEY, 1991).

Enzymatic activity - Falling Number (Table 1) remained constant on the different formulations. This behavior is correlated with the unaltered moisture content mentioned above.

The amount of ashes increased significantly $(p<0.05)$ and was directly proportional to 
fiber concentration (Table 1). This result can be attributed to the fact that the fiber is extracted near the peel of the seed, where the highest amount of minerals can be found (SEIBEL \& BELEIA, 2008).

The color analysis, in relation to the $L^{*}$ parameter, showed significant $(p<0.05)$ darkening with increased fiber concentrations (Table 1), the control having the lightest color. Similar result was obtained when the $a^{*}$ parameter was used: a significant $(p<0.05)$ intensification of the green as the concentration of soy increased (Table 1). These results are similar to those obtained by Peressini \& Sensidoni (2009), who reported that the addition of fibers result in darker colored pasta.

All formulations with addition of soy fiber resulted in higher percentage of retained gluten $(p<0.05)$ when compared with the control (Table 1). Elevated concentration of retained gluten results in increased firmness during molding and cooking, producing a more uniform thread with homogenous diameter along its entire length (PERESSINI \& SENSIDONI, 2009; HAARD, 1992).

\section{TABLE 1 - PHYSICOCHEMICAL AND RHEOLOGICAL PROPERTIES OF WHEAT FLOWER WITH DIFFERENT CONCENTRATIONS OF SOY FIBER}

\begin{tabular}{|c|c|c|c|c|c|}
\hline \multirow{2}{*}{\multicolumn{2}{|c|}{ Properties }} & \multirow[b]{2}{*}{ Control } & \multicolumn{3}{|c|}{ FORMULATIONS } \\
\hline & & & $4 \%$ & $6 \%$ & $8 \%$ \\
\hline \multicolumn{2}{|c|}{ Moisture(\%) } & $13.8 \pm 0.06^{\mathrm{ab}}$ & $13.9 \pm 0.1^{b}$ & $13.7 \pm 0.06^{a}$ & $13.7 \pm 0.06^{a}$ \\
\hline \multicolumn{2}{|c|}{ Falling Number (seg) } & $345.3 \pm 4.6^{\mathrm{a}}$ & $347.0 \pm 5.3^{a}$ & $352.3 \pm 5.8^{a}$ & $355.3 \pm 4.9^{a}$ \\
\hline \multicolumn{2}{|c|}{ Ashes (\%) } & $0.5 \pm 0.01^{a}$ & $0.6 \pm 0.01^{b}$ & $0.7 \pm 0.002^{c}$ & $0.8 \pm 0.003^{d}$ \\
\hline \multirow{2}{*}{$\frac{\overline{0}}{0}$} & $\mathrm{~L}^{*}$ & $92.8 \pm 0.01^{d}$ & $92.0 \pm 0.09^{c}$ & $91.7 \pm 0.03^{b}$ & $91.4 \pm 0.05^{a}$ \\
\hline & $a^{*}$ & $-0.9 \pm 0.03 a$ & $-0.7 \pm 0.01 b$ & $-0.6 \pm 0.01 c$ & $-0.5 \pm 0.01^{d}$ \\
\hline \multicolumn{2}{|c|}{ Retained gluten (\%) } & $26.6 \pm 0.4^{a}$ & $28.6 \pm 0.8^{b}$ & $28.5 \pm 0.1^{\mathrm{b}}$ & $29.3 \pm 0.3^{b}$ \\
\hline \multirow{3}{*}{ 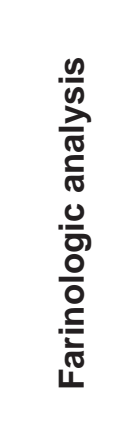 } & $\begin{array}{l}\text { Water } \\
\text { absorption } \\
\text { (\%) }\end{array}$ & $58.3 \pm 0.2^{\mathrm{a}}$ & $64.9 \pm 0.6^{b}$ & $69.0 \pm 0.4^{c}$ & $72.8 \pm 0.5^{d}$ \\
\hline & $\begin{array}{l}\text { Development } \\
\text { time (min) }\end{array}$ & $7.7 \pm 0.3^{a}$ & $10.6 \pm 1.4^{\mathrm{ab}}$ & $12.6 \pm 0.7^{\mathrm{b}}$ & $13.4 \pm 1.7^{b}$ \\
\hline & Stability (min) & $13.8 \pm 0.7^{a}$ & $15.9 \pm 1.9^{a}$ & $20.1 \pm 0.3^{b}$ & $21.7 \pm 0.4^{b}$ \\
\hline \multirow{2}{*}{ 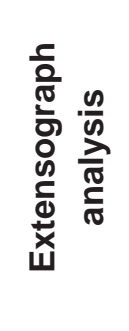 } & $\begin{array}{l}\text { Resistence } \\
\text { (UB - unity } \\
\text { Brabender) }\end{array}$ & $314.0 \pm 23.3^{a}$ & $355.0 \pm 10.5^{a}$ & $385.0 \pm 38.1^{a}$ & $353.3 \pm 38.4^{a}$ \\
\hline & $\begin{array}{l}\text { Extensibility } \\
(\mathrm{mm})\end{array}$ & $164.7 \pm 1.5^{c}$ & $128.3 \pm 4.0^{\mathrm{b}}$ & $115.7 \pm 8.1^{\mathrm{a}}$ & $113.7 \pm 2.9^{a}$ \\
\hline
\end{tabular}

Means with the same exponent, on the same row, do not differ according to Turkey test $(p<0.05)$. 
Water retention increased significantly $(p<0.05)$ with higher concentrations of soy fiber (Table 1). These changes are attributed to the formation of a gluten net with higher capacity to retain water (HAARD, 1992; CHANG \& FLORES, 2004). The latter authors also noted that addition of soy fiber gives more elasticity to the pasta.

The addition of soy fiber at concentrations of $6 \%$ and above extended significantly the development time of the flour (Table 1). These results, in connection with water absorption, indicate that the mixture has the characteristics of strong flour, which is related to the proteic quality of the gluten net (PAUCAR-MENACHO et al., 2008).

In regards to stability, two statistically distinct groups were obtained $(p<0.05)$. The first group included the control and the formulation with $4 \%$ added soy fiber; the second group included the formulations with $6 \%$ and $8 \%$ soy fiber, respectively. The pasta with higher concentrations of fiber presented higher stability when kneaded and better technological quality, indicating the presence of a crosslink between protein molecules present in the gluten (INDRANI \& RAO, 2007). The addition of soy fiber did not interfere significantly with the resistance parameter $(p<0.05)$ or elasticity of the pasta (Table 1). However, it had a significant $(p<0.05)$ effect on extensibility, indicating that the resulting pasta was more heterogeneous and more fragile (WANG et al., 2003; ZAIDEL et al., 2008).

\subsection{SPAGHETTI ANALYSIS}

In the performance test, used to quantify the degree of stickiness (Table 2), the spaghetti with added soy fiber resulted in a less sticky and better quality pasta than the control. This behavior is a result of the proteic net formed with the soy fiber, which buffers the internal humidity levels by slowing down water loss and the formation of nodules (CHANG \& FLORES, 2004).

The values for volume increase (Table 2) showed significant variations $(p<0.05)$ for the $4 \%$ and $6 \%$ formulations, and were similar to those obtained for the control.

Formulations containing soy fibers showed significantly lower amount of soluble solids loss to water $(p<0.05)$, indicating that the addition of soy fibers contributed to the stability of the starch during cooking. These results relate to those obtained in the cooking test, which has indicated that the higher amount of lost amylase results on a spaghetti that is stickier after draining (PERESSINI \& SENSIDONI, 2009).

\section{TABLE 2 - MEAN VALUES OF THE ATTRIBUTES OBTAINED FROM THE DRY SPAGHETTI COOKING TEST WITH AND WITHOUT ADDITION OF SOY FIBER}

FORMULATIONS

\begin{tabular}{lcccc}
\hline \multicolumn{1}{c}{ Attributes } & Control & $4 \%$ & $\mathbf{6 \%}$ & $\mathbf{8 \%}$ \\
\hline Performance (grades 0 -5) & $3.3 \pm 0.6^{\mathrm{a}}$ & $4.0 \pm 0.0^{\mathrm{ab}}$ & $4.3 \pm 0.6^{\mathrm{ab}}$ & $5.0 \pm 0.0^{\mathrm{b}}$ \\
\hline $\begin{array}{l}\text { Pasta volume increase } \\
\text { (after cooked) (\%) }\end{array}$ & $152.3 \pm 0.6^{\mathrm{ab}}$ & $153.0 \pm 0.0^{\mathrm{b}}$ & $152.7 \pm 0.3^{\mathrm{ab}}$ & $152.0 \pm 0.0^{\mathrm{a}}$ \\
\hline $\begin{array}{l}\text { Loss of soluble solids to } \\
\text { cooking water (\%) }\end{array}$ & $32.6 \pm 2.7^{\mathrm{b}}$ & $22.6 \pm 0.1^{\mathrm{a}}$ & $20.1 \pm 0.2^{\mathrm{a}}$ & $18.8 \pm 2.1^{\mathrm{a}}$ \\
\hline
\end{tabular}

Means with the same exponent, on the same row, do not differ according to Turkey test $(p<0.05)$. 


\subsection{SENSORY ANALYSIS}

Panelists have noted a significant difference $(p<0.05)$ in all attributes when comparing formulations with $8 \%$ soy fiber against the control. Decreasing scores were given to increasing concentrations of soy fiber (Table 3). However, formulations with $4 \%$ and $6 \%$ addition of soy fiber were well accepted with scores from five to seven, indicating that panelists were either indifferent to or liked the formulations. The attributes of chewability and firmness were less affected by the addition of soy in the concentrations of 4 and $6 \%$.

TABLE 3 - MEAN GRADES ATTRIBUTED TO COLOR, TASTE, CHEWABILITY, FIRMNESS AND ELASTICITY, COMPARING SAMPLES OF WHEAT SPAGHETTI WITH AND WITHOUT ADDITION OF SOY FIBER IN THREE DIFFERENT CONCENTRATIONS

\begin{tabular}{ccccc}
\hline & & \multicolumn{3}{c}{ FORMULATIONS } \\
\hline Sample & Control & $4 \%$ & $6 \%$ & $8 \%$ \\
\hline Color & $7,2 \pm 1,5^{\mathrm{b}}$ & $5,8 \pm 1,9^{\mathrm{ab}}$ & $5,7 \pm 1,8^{\mathrm{ab}}$ & $4,0 \pm 1,4^{\mathrm{a}}$ \\
\hline Taste & $6,7 \pm 1,1^{\mathrm{b}}$ & $6,2 \pm 1,5^{\mathrm{ab}}$ & $5,8 \pm 1,9^{\mathrm{ab}}$ & $4,5 \pm 1,8^{\mathrm{a}}$ \\
\hline Chewability & $7,1 \pm 1,3^{\mathrm{b}}$ & $7,3 \pm 1,1^{\mathrm{b}}$ & $6,0 \pm 1,3^{\mathrm{ab}}$ & $4,8 \pm 1,5^{\mathrm{a}}$ \\
\hline Firmness & $6,6 \pm 1,1^{\mathrm{b}}$ & $6,8 \pm 0,8^{\mathrm{b}}$ & $6,7 \pm 1,4^{\mathrm{b}}$ & $4,1 \pm 1,3^{\mathrm{a}}$ \\
\hline Elasticity & $6,9 \pm 0,8^{\mathrm{c}}$ & $6,5 \pm 1,4^{\mathrm{bc}}$ & $5,2 \pm 1,4^{\mathrm{ab}}$ & $4,1 \pm 1,8^{\mathrm{a}}$ \\
\hline
\end{tabular}

Means with the same exponent, on the same row, do not differ according to Turkey test $(p<0.05)$.

\section{CONCLUSION}

The mixtures of wheat flower and soy fiber in the proportion of $6 \%$ and $8 \%$ obtained best scores according to the extensograph and farinograph analyses, respectively, meaning that they are suitable for being commercialized. Soy fiber addition had a positive impact, significantly $(p<0.05)$ influencing performance and reducing the loss of soluble solids to cooking water. Nevertheless, sensory analysis revealed that the panelists gave preference to spaghetti with up to $6 \%$ soy fiber for the parameters measured. In conclusion, it is possible to add soy fiber to wheat flower, thus producing wheat pasta type spaghetti with better rheological and nutritional characteristics.

\section{RESUMO}

\section{AVALIAÇÃO DA ADIÇÃO DE FIBRA DE SOJA EM MASSAS ALIMENTÍ́CIAS TIPO ESPAGUETE}

Avaliaram-se os efeitos da adição de 4\%, $6 \%$ e $8 \%$ de fibra de soja em mistura de farinha de trigo para produção de massa alimentícia seca tipo espaguete. As propriedades da mistura de farinha de trigo com fibra de soja foram determinadas mediante análises de umidade, falling number, cinzas, cor, glúten retido, farinografia (absorção de água, desenvolvimento e estabilidade) e de extensografia (resistência e extensibilidade). Avaliou- 
se a massa alimentícia resultante por meio de testes de cozimento (desempenho, aumento de volume e perda de sólidos solúveis na água de cozimento) e análise sensorial. A adição de fibra de soja às farinhas de trigo resultou em misturas com características reológicas e físico-químicas aptas para a fabricação de massas tipo espaguete, proporcionando aumento de desempenho e a redução das perdas de sólidos solúveis na água de cozimento. A análise sensorial demonstrou que os julgadores preferiram massas com adição de até $6 \%$ de fibra de soja em todos os parâmetros analisados.

PALAVRAS-CHAVE: ANÁLISE SENSORIAL; ALIMENTO FUNCIONAL; FIBRA DE SOJA; MACARRÃO.

\section{REFERENCES}

1 AACC. American Association of Cereal Chemists.Approved methods of the American Association of Cereal Chemists. Saint Paul, 1995.

2 AACC. American Association of Cereal Chemists. Approved methods of the American Association of Cereal Chemists. Saint Paul, 1983

3 BAHNASSEY, Y.; KHAN, K. Fortification of spaghetti 392 with edible legumes. II Rheological, processing and quality evaluations studies. Cereal Chemistry, v.63,p. 216-219, 1986.

4 BAIANO, A.; CONTE, A.; DELNOBILE, M.A. Influence of drying temperature on the spaghetti cooking quality. Journal of Food Engineering, v.76, p. 341-347, 2006.

5 BOSAEUS, I. Fibre effects on intestinal functions (diarrhoea, constipation and irritable bowel syndrome).Clinical Nutrition Supplements, v.1, p. 33-38, 2004.

6 CHANG, Y.K.; FLORES, H.E.M. Qualidade tecnológica de massas alimentícias frescas elaboradas de semolina de trigo durum ( $T$. durumL.) e farinha de trigo ( $T$. aestivum L.) Ciência e Tecnologia de Alimentos, v. 24, p. 487-493, 2004.

7 CHILLO, S.; LAVERSE, J.; FALCONE, P.M.; PROTOPAPA, A.; DEL NOBILE, M.A. Influence of the addition of buckwheat flour and durum wheat bran on spaghetti quality. Journal of Cereal Science, v.47, p. 144-152, 2008a.

8 CHILLO, S.; LAVERSE, J.; FALCONE, P.M.; DEL NOBILE, M.A. Quality of spaghetti in base amaranthus wholemeal flour added with quinoa, broad bean and chick pea. Journal of Food Engineering, v.84, p. 101-107, 2008b.

9 HAARD, N.F. Características de los tejidos vegetales comestibles. In: FENNEMA, O. R. (Ed.). Química de los alimentos. Zaragoza: Acribia, 1992. p. 966-967.

10 HOSENEY, R.C. Principios de ciencia y tecnología de los cereales. Zaragoza: Acribia 1991

11 ICC. International Association for Cereal Chemistry. Standard method n. 104/01: method for determination of ash in cereals and cereal products. Vienna, Austria, 1990.

12 INDRANI, D.; RAO, G.V. Rheological characteristics of wheat flour dough as influenced by ingredients of Parotta. Journal of Food Engineering, v.17, p. 110-105, 2007.

13 KNUCKLES, B.E.; HUDSON, C.A.; CHIU, M.M.; SAYRE, R.N. Effect of $\beta$-glucan barley fractions in high fiber bread and pasta. Cereal Foods World, v.42, p. 94-99, 1997

14 MARCONI, E.; CARCEA, M. Pasta from non traditional raw materials. Cereal Foods World, v.46, p. 522-529, 2001.

15 MINOLTA CO. Chroma meter CR300: instruction manual. Osaka, 1991.

16 MORAES, M.A.C. Métodos para avaliação sensorial dos alimentos. Campinas: Editora da UNICAMP, 1993.

17 PAUCAR-MENACHO, L.M.; SILVA, L,H.; BARRETTO, P.A.A.; MAZAL, G.; FAKHOURI, F.M.; STEEL, C.J.; COLLARESQUEIROZ, F.P. Desenvolvimento de massa alimentícia fresca funcional com a adição de isolado protéico de soja e polidextrose utilizando páprica como corante. Ciência e Tecnologia de Alimentos, v.28, p. 767-778, 2008.

18 PERESSINI, D.; SENSIDONI, A. Effect of soluble dietary fibre addition on rheological and breadmaking properties of wheat doughs. Journal of Cereal Science, v.49, p. 190-201, 2009.

19 ROSTAGNO, M.A.; PALMA, M.; BARROSO, C.G. Short-term stability of soy isoflavones extracts: sample conservation aspects. Food Chemistry, v.93, p. 557-564, 2005.

20 SCHEPPACH, W.; LUEHRS, H.; MELCHER, R.; GOSTNER, A.; SCHAUBER, J.; KUDLICH, T.; WEILER, F.; MENZEL, T. Antiinflammatory and anticarcinogenic effects of dietary fibre. Clinical Nutrition Supplements, v.1, p.51-58, 2004. 
21 SEIBEL, N.F.; BELEIA, A.D.P. Carboidratos das fibras de cotilédones e proteínas de produtos derivados de soja (Glycinemax (L.) Merril). Ciência e Tecnologia de Alimentos, v. 28, p. 607-613, 2008.

22 TOLEDO SCALE INDUSTRY OF BRAZIL LTDA. The user manual OHAUS model MB200. New Jersey, 1995.

23 WANG, M.; HAMER, R.J.; VAN VLIET, T.; GRUPPEN, H.; MARSEILLE, H.; WEEGELS, P.L. Effect of water unextractable solids on gluten formation and properties: mechanistic considerations. Journal of Cereal Science, v.37, p.55-64, 2003.

24 ZAIDEL, D.N.A.; CHIN, N.L.; RAHMAN, R.A.; KARIM, R. Rheological characterization of gluten from extensibility measurement. Journal of Food Engineering, v.86, p.549-556, 2008. 


\title{
THE EFFECTS OF ADDING SOY FIBER TO WHEAT SPAGHETTI
}

\begin{abstract}
This study has evaluated the effects of adding $4 \%, 6 \%$ and $8 \%$ soy fiber to wheat pasta for the production of dry wheat spaghetti. The properties of the mixture were evaluated for humidity, falling number, ashes, color, retained gluten, and subjected to farinograph (water absorption, development, stability) and extensograph analyses (resistance and extensibility). The spaghetti was evaluated with cooking tests (performance, increased volume, loss of soluble solids to cooking water) and sensory analysis. The addition of soy fiber to wheat flour resulted in mixtures with rheological and physicochemical characteristics suitable for the production of wheat spaghetti, enhancing performance and reducing the loss of soluble solids to the cooking water. The sensory analysis showed that, for all parameters tested, panelists favored mixtures with up to $6 \%$ soy fiber addition.
\end{abstract}

KEY-WORDS: SENSORY ANALYSIS; FUNCTIONAL FOOD; SOY FIBER.

* Engenheira de Alimentos,Universidade de Caxias do Sul (UCS), Caxias do Sul, RS (e-mail: alinebenedetti@ gmail.com).

** Engenheira de Alimentos, Professora, Faculdade UnB Planaltina, Planaltina, DF (e-mail: vaniars@unb. br). 


\section{INTRODUCTION}

According to the World Health Organization (WHO) and the Food and Drug Administration (FDA), pasta is a good product for the addition of nutrients (CHILLO et al., 2008b), and possesses several other positive qualities including extended shelf life and high carbohydrate content (CHILLO et al., 2008a).

Spaghetti was the first food to receive FDA authorization for the addition of vitamins and iron, in 1940 (MARCONI \& CARCEA, 2001). Since then, various studies have been conducted to evaluate the addition of fiber, proteins of plant origin, as well as vitamins and minerals to improve the nutritional value of spaghetti (BAHNASSEY \& KHAN, 1986; KNUCKLES et al., 1997).

Fibers are not digested by humans but ferment in the presence of bacteria that inhabit the colon; these bacteria produce lactic acids and break down fatty acids into short chains, thus helping reduce blood cholesterol levels. An adequate intake of fibers may help to prevent, or aid in the treatment of obesity, diabetes, colon cancer, ulcers and coronary diseases (BOSAEUS, 2004; SCHEPPACH et al., 2004). Because of the perceived benefits of fibers intake, researchers have shown great interest about them (ROSTAGNO, PALMA \& BARROSO, 2005). Soy fiber is mainly composed of carbohydrates from the cotyledon walls, without peel contamination (SEIBEL \& BELEIA, 2008).

The addition of fibers may change the rheological and physicochemical properties of flours during cooking (ROSTAGNO, PALMA \& BARROSO, 2005; BAIANO, CONTE \& DELNOBILE, 2006; CHILLO et al., 2008b).

The present study aimed to evaluate how the addition of soy fiber to a wheat flour mixture affects the behavior of wheat spaghetti.

\section{MATERIAL AND METHODS}

Soy fiber FIBRARICH FB 20 (The Solae Company) was added to a mixture of wheat flour Orquídea Especial MI (Tondo S/A) and water (40.25\%) in the following concentrations: $4 \%, 6 \% \mathrm{e}$ $8 \%$.

Wheat flour and soy fiber mixtures were formulated and dry pasta was processed at the Tondo S/A - Unidade Forqueta (Caxias do Sul - RS/Brazil) in laboratorial scale. The ingredients that make up the dry mixture were homogenized with the help of a mixer (Extrusora Men 8 - Monte Castelo), followed by the addition of water for 10 minutes. Next, the mixture was molded in the shape of spaghetti using a trafile (Monte Castelo).

The formulations included a control (without addition of soy) and soy fiber added to the wheat mixture in different proportions.

\subsection{ANALYSIS OF THE MIXTURE OF WHEAT FLOUR AND SOY FIBER}

The following rheological and physicochemical analyses were conducted on the wheat flour added with soy mixtures:

- Humidity, determined by an Infrared Moisture Analyzer, OHAUS, MB200 (TOLEDO), 1995;

- Falling Number, method AACC n. 56-81 (AACC, 1995);

- Ashes method ICC n.104/1 (ICC, 1990);

- Color analysis (parameters $L^{*}, a^{*}$ ) determined by Colorimeter Minolta, model CR300s (MINOLTA, 1991);

- Retained gluten analysis by method AACC n. 38-12 (AACC, 1995); 
- Farinologic analysis (water absorption) method AACC n. 54-20 (AACC, 1995);

- Extensograph analysis (resistance and flexibility), method AACC n. 54-10 (AACC, 1995).

\subsection{SPAGHETTI ANALYSIS}

The spaghetti was evaluated with a cooking test following the method AACC (1983) n.16-50 and considered the following parameters:

\section{- Spaghetti performance}

The stickiness after cooking was evaluated using the following scale: 5 - very tender, separate; 4 - completely separate; 3 - mildly stuck together; 2 - stuck together; 1 - very stuck together; 0 - completely stuck together.

In order to ascertain whether the product was cooked, samples were taken regularly and the presence of the central thread was evaluated. The product was considered cooked (al dente) when the central thread was no longer present, a criterion adopted by the Toronto Industries S/A - Unidade Forqueta (Caxias do Sul - RS/Brazil).

\section{- Increase in volume}

The increase in volume after cooking was determined in the following manner: samples were immersed in $140 \mathrm{~mL}$ hexane; the volume of hexane displaced by either cooked or raw pasta was calculated. The results were written as a function of the number of times the pasta increased in volume.

\section{- Loss of soluble solids or residues to cooking water}

The amount of soluble solids in cooking water was determined by the evaporation of a $25 \mathrm{~mL}$ sample in a stove at $110^{\circ} \mathrm{C}$ until a constant weight was reached. The results were written as percentage of the difference between the total mass before and after water evaporated.

\subsection{SENSORY ANALYSIS}

The sensory analysis of the wheat spaghetti with added fiber was performed by untrained panelist using a profile test feature. Color, taste, chewability, firmness and elasticity of the food were rated through a 9-point hedonic scale with the following extremes: I disliked it very much (1) I liked it very much (9) (MORAIS, 1993).

\section{RESULTS AND DISCUSSION}

\subsection{ANALYSIS OF THE WHEAT FLOUR WITH SOY FIBER MIXTURE}

The addition of soy fiber did not significantly interfere with the moisture content of the formulations $(p<0.05)$ when compared to control (Table 1$)$. This result is very important because moisture content affects the activity of the alfa-amylase, an enzyme that controls viscosity through the amylolytic hydrolysis of the starch (HOSENEY, 1991).

Enzymatic activity - Falling Number (Table 1) remained constant on the different formulations. This behavior is correlated with the unaltered moisture content mentioned above.

The amount of ashes increased significantly $(p<0.05)$ and was directly proportional to 
fiber concentration (Table 1). This result can be attributed to the fact that the fiber is extracted near the peel of the seed, where the highest amount of minerals can be found (SEIBEL \& BELEIA, 2008).

The color analysis, in relation to the $L^{*}$ parameter, showed significant $(p<0.05)$ darkening with increased fiber concentrations (Table 1), the control having the lightest color. Similar result was obtained when the $a^{*}$ parameter was used: a significant $(p<0.05)$ intensification of the green as the concentration of soy increased (Table 1). These results are similar to those obtained by Peressini \& Sensidoni (2009), who reported that the addition of fibers result in darker colored pasta.

All formulations with addition of soy fiber resulted in higher percentage of retained gluten $(p<0.05)$ when compared with the control (Table 1). Elevated concentration of retained gluten results in increased firmness during molding and cooking, producing a more uniform thread with homogenous diameter along its entire length (PERESSINI \& SENSIDONI, 2009; HAARD, 1992).

\section{TABLE 1 - PHYSICOCHEMICAL AND RHEOLOGICAL PROPERTIES OF WHEAT FLOWER WITH DIFFERENT CONCENTRATIONS OF SOY FIBER}

\begin{tabular}{|c|c|c|c|c|c|}
\hline \multirow{2}{*}{\multicolumn{2}{|c|}{ Properties }} & \multirow[b]{2}{*}{ Control } & \multicolumn{3}{|c|}{ FORMULATIONS } \\
\hline & & & $4 \%$ & $6 \%$ & $8 \%$ \\
\hline \multicolumn{2}{|c|}{ Moisture(\%) } & $13.8 \pm 0.06^{\mathrm{ab}}$ & $13.9 \pm 0.1^{b}$ & $13.7 \pm 0.06^{a}$ & $13.7 \pm 0.06^{a}$ \\
\hline \multicolumn{2}{|c|}{ Falling Number (seg) } & $345.3 \pm 4.6^{\mathrm{a}}$ & $347.0 \pm 5.3^{a}$ & $352.3 \pm 5.8^{a}$ & $355.3 \pm 4.9^{a}$ \\
\hline \multicolumn{2}{|c|}{ Ashes (\%) } & $0.5 \pm 0.01^{a}$ & $0.6 \pm 0.01^{b}$ & $0.7 \pm 0.002^{c}$ & $0.8 \pm 0.003^{d}$ \\
\hline \multirow{2}{*}{$\frac{\overline{0}}{0}$} & $\mathrm{~L}^{*}$ & $92.8 \pm 0.01^{d}$ & $92.0 \pm 0.09^{c}$ & $91.7 \pm 0.03^{b}$ & $91.4 \pm 0.05^{a}$ \\
\hline & $a^{*}$ & $-0.9 \pm 0.03 a$ & $-0.7 \pm 0.01 b$ & $-0.6 \pm 0.01 c$ & $-0.5 \pm 0.01^{d}$ \\
\hline \multicolumn{2}{|c|}{ Retained gluten (\%) } & $26.6 \pm 0.4^{a}$ & $28.6 \pm 0.8^{b}$ & $28.5 \pm 0.1^{\mathrm{b}}$ & $29.3 \pm 0.3^{b}$ \\
\hline \multirow{3}{*}{ 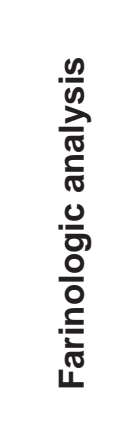 } & $\begin{array}{l}\text { Water } \\
\text { absorption } \\
\text { (\%) }\end{array}$ & $58.3 \pm 0.2^{\mathrm{a}}$ & $64.9 \pm 0.6^{b}$ & $69.0 \pm 0.4^{c}$ & $72.8 \pm 0.5^{d}$ \\
\hline & $\begin{array}{l}\text { Development } \\
\text { time (min) }\end{array}$ & $7.7 \pm 0.3^{a}$ & $10.6 \pm 1.4^{\mathrm{ab}}$ & $12.6 \pm 0.7^{\mathrm{b}}$ & $13.4 \pm 1.7^{b}$ \\
\hline & Stability (min) & $13.8 \pm 0.7^{a}$ & $15.9 \pm 1.9^{a}$ & $20.1 \pm 0.3^{b}$ & $21.7 \pm 0.4^{b}$ \\
\hline \multirow{2}{*}{ 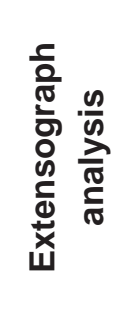 } & $\begin{array}{l}\text { Resistence } \\
\text { (UB - unity } \\
\text { Brabender) }\end{array}$ & $314.0 \pm 23.3^{a}$ & $355.0 \pm 10.5^{a}$ & $385.0 \pm 38.1^{a}$ & $353.3 \pm 38.4^{a}$ \\
\hline & $\begin{array}{l}\text { Extensibility } \\
(\mathrm{mm})\end{array}$ & $164.7 \pm 1.5^{c}$ & $128.3 \pm 4.0^{\mathrm{b}}$ & $115.7 \pm 8.1^{\mathrm{a}}$ & $113.7 \pm 2.9^{a}$ \\
\hline
\end{tabular}

Means with the same exponent, on the same row, do not differ according to Turkey test $(p<0.05)$. 
Water retention increased significantly $(p<0.05)$ with higher concentrations of soy fiber (Table 1). These changes are attributed to the formation of a gluten net with higher capacity to retain water (HAARD, 1992; CHANG \& FLORES, 2004). The latter authors also noted that addition of soy fiber gives more elasticity to the pasta.

The addition of soy fiber at concentrations of $6 \%$ and above extended significantly the development time of the flour (Table 1). These results, in connection with water absorption, indicate that the mixture has the characteristics of strong flour, which is related to the proteic quality of the gluten net (PAUCAR-MENACHO et al., 2008).

In regards to stability, two statistically distinct groups were obtained $(p<0.05)$. The first group included the control and the formulation with $4 \%$ added soy fiber; the second group included the formulations with $6 \%$ and $8 \%$ soy fiber, respectively. The pasta with higher concentrations of fiber presented higher stability when kneaded and better technological quality, indicating the presence of a crosslink between protein molecules present in the gluten (INDRANI \& RAO, 2007). The addition of soy fiber did not interfere significantly with the resistance parameter $(p<0.05)$ or elasticity of the pasta (Table 1). However, it had a significant $(p<0.05)$ effect on extensibility, indicating that the resulting pasta was more heterogeneous and more fragile (WANG et al., 2003; ZAIDEL et al., 2008).

\subsection{SPAGHETTI ANALYSIS}

In the performance test, used to quantify the degree of stickiness (Table 2), the spaghetti with added soy fiber resulted in a less sticky and better quality pasta than the control. This behavior is a result of the proteic net formed with the soy fiber, which buffers the internal humidity levels by slowing down water loss and the formation of nodules (CHANG \& FLORES, 2004).

The values for volume increase (Table 2) showed significant variations $(p<0.05)$ for the $4 \%$ and $6 \%$ formulations, and were similar to those obtained for the control.

Formulations containing soy fibers showed significantly lower amount of soluble solids loss to water $(p<0.05)$, indicating that the addition of soy fibers contributed to the stability of the starch during cooking. These results relate to those obtained in the cooking test, which has indicated that the higher amount of lost amylase results on a spaghetti that is stickier after draining (PERESSINI \& SENSIDONI, 2009).

\section{TABLE 2 - MEAN VALUES OF THE ATTRIBUTES OBTAINED FROM THE DRY SPAGHETTI COOKING TEST WITH AND WITHOUT ADDITION OF SOY FIBER}

FORMULATIONS

\begin{tabular}{lcccc}
\hline \multicolumn{1}{c}{ Attributes } & Control & $4 \%$ & $\mathbf{6 \%}$ & $\mathbf{8 \%}$ \\
\hline Performance (grades 0 -5) & $3.3 \pm 0.6^{\mathrm{a}}$ & $4.0 \pm 0.0^{\mathrm{ab}}$ & $4.3 \pm 0.6^{\mathrm{ab}}$ & $5.0 \pm 0.0^{\mathrm{b}}$ \\
\hline $\begin{array}{l}\text { Pasta volume increase } \\
\text { (after cooked) (\%) }\end{array}$ & $152.3 \pm 0.6^{\mathrm{ab}}$ & $153.0 \pm 0.0^{\mathrm{b}}$ & $152.7 \pm 0.3^{\mathrm{ab}}$ & $152.0 \pm 0.0^{\mathrm{a}}$ \\
\hline $\begin{array}{l}\text { Loss of soluble solids to } \\
\text { cooking water (\%) }\end{array}$ & $32.6 \pm 2.7^{\mathrm{b}}$ & $22.6 \pm 0.1^{\mathrm{a}}$ & $20.1 \pm 0.2^{\mathrm{a}}$ & $18.8 \pm 2.1^{\mathrm{a}}$ \\
\hline
\end{tabular}

Means with the same exponent, on the same row, do not differ according to Turkey test $(p<0.05)$. 


\subsection{SENSORY ANALYSIS}

Panelists have noted a significant difference $(p<0.05)$ in all attributes when comparing formulations with $8 \%$ soy fiber against the control. Decreasing scores were given to increasing concentrations of soy fiber (Table 3). However, formulations with $4 \%$ and $6 \%$ addition of soy fiber were well accepted with scores from five to seven, indicating that panelists were either indifferent to or liked the formulations. The attributes of chewability and firmness were less affected by the addition of soy in the concentrations of 4 and $6 \%$.

TABLE 3 - MEAN GRADES ATTRIBUTED TO COLOR, TASTE, CHEWABILITY, FIRMNESS AND ELASTICITY, COMPARING SAMPLES OF WHEAT SPAGHETTI WITH AND WITHOUT ADDITION OF SOY FIBER IN THREE DIFFERENT CONCENTRATIONS

\begin{tabular}{ccccc}
\hline & & \multicolumn{3}{c}{ FORMULATIONS } \\
\hline Sample & Control & $4 \%$ & $6 \%$ & $8 \%$ \\
\hline Color & $7,2 \pm 1,5^{\mathrm{b}}$ & $5,8 \pm 1,9^{\mathrm{ab}}$ & $5,7 \pm 1,8^{\mathrm{ab}}$ & $4,0 \pm 1,4^{\mathrm{a}}$ \\
\hline Taste & $6,7 \pm 1,1^{\mathrm{b}}$ & $6,2 \pm 1,5^{\mathrm{ab}}$ & $5,8 \pm 1,9^{\mathrm{ab}}$ & $4,5 \pm 1,8^{\mathrm{a}}$ \\
\hline Chewability & $7,1 \pm 1,3^{\mathrm{b}}$ & $7,3 \pm 1,1^{\mathrm{b}}$ & $6,0 \pm 1,3^{\mathrm{ab}}$ & $4,8 \pm 1,5^{\mathrm{a}}$ \\
\hline Firmness & $6,6 \pm 1,1^{\mathrm{b}}$ & $6,8 \pm 0,8^{\mathrm{b}}$ & $6,7 \pm 1,4^{\mathrm{b}}$ & $4,1 \pm 1,3^{\mathrm{a}}$ \\
\hline Elasticity & $6,9 \pm 0,8^{\mathrm{c}}$ & $6,5 \pm 1,4^{\mathrm{bc}}$ & $5,2 \pm 1,4^{\mathrm{ab}}$ & $4,1 \pm 1,8^{\mathrm{a}}$ \\
\hline
\end{tabular}

Means with the same exponent, on the same row, do not differ according to Turkey test $(p<0.05)$.

\section{CONCLUSION}

The mixtures of wheat flower and soy fiber in the proportion of $6 \%$ and $8 \%$ obtained best scores according to the extensograph and farinograph analyses, respectively, meaning that they are suitable for being commercialized. Soy fiber addition had a positive impact, significantly $(p<0.05)$ influencing performance and reducing the loss of soluble solids to cooking water. Nevertheless, sensory analysis revealed that the panelists gave preference to spaghetti with up to $6 \%$ soy fiber for the parameters measured. In conclusion, it is possible to add soy fiber to wheat flower, thus producing wheat pasta type spaghetti with better rheological and nutritional characteristics.

\section{RESUMO}

\section{AVALIAÇÃO DA ADIÇÃO DE FIBRA DE SOJA EM MASSAS ALIMENTÍ́CIAS TIPO ESPAGUETE}

Avaliaram-se os efeitos da adição de 4\%, $6 \%$ e $8 \%$ de fibra de soja em mistura de farinha de trigo para produção de massa alimentícia seca tipo espaguete. As propriedades da mistura de farinha de trigo com fibra de soja foram determinadas mediante análises de umidade, falling number, cinzas, cor, glúten retido, farinografia (absorção de água, desenvolvimento e estabilidade) e de extensografia (resistência e extensibilidade). Avaliou- 
se a massa alimentícia resultante por meio de testes de cozimento (desempenho, aumento de volume e perda de sólidos solúveis na água de cozimento) e análise sensorial. A adição de fibra de soja às farinhas de trigo resultou em misturas com características reológicas e físico-químicas aptas para a fabricação de massas tipo espaguete, proporcionando aumento de desempenho e a redução das perdas de sólidos solúveis na água de cozimento. A análise sensorial demonstrou que os julgadores preferiram massas com adição de até $6 \%$ de fibra de soja em todos os parâmetros analisados.

PALAVRAS-CHAVE: ANÁLISE SENSORIAL; ALIMENTO FUNCIONAL; FIBRA DE SOJA; MACARRÃO.

\section{REFERENCES}

1 AACC. American Association of Cereal Chemists.Approved methods of the American Association of Cereal Chemists. Saint Paul, 1995.

2 AACC. American Association of Cereal Chemists. Approved methods of the American Association of Cereal Chemists. Saint Paul, 1983

3 BAHNASSEY, Y.; KHAN, K. Fortification of spaghetti 392 with edible legumes. II Rheological, processing and quality evaluations studies. Cereal Chemistry, v.63,p. 216-219, 1986.

4 BAIANO, A.; CONTE, A.; DELNOBILE, M.A. Influence of drying temperature on the spaghetti cooking quality. Journal of Food Engineering, v.76, p. 341-347, 2006.

5 BOSAEUS, I. Fibre effects on intestinal functions (diarrhoea, constipation and irritable bowel syndrome).Clinical Nutrition Supplements, v.1, p. 33-38, 2004.

6 CHANG, Y.K.; FLORES, H.E.M. Qualidade tecnológica de massas alimentícias frescas elaboradas de semolina de trigo durum ( $T$. durumL.) e farinha de trigo ( $T$. aestivum L.) Ciência e Tecnologia de Alimentos, v. 24, p. 487-493, 2004.

7 CHILLO, S.; LAVERSE, J.; FALCONE, P.M.; PROTOPAPA, A.; DEL NOBILE, M.A. Influence of the addition of buckwheat flour and durum wheat bran on spaghetti quality. Journal of Cereal Science, v.47, p. 144-152, 2008a.

8 CHILLO, S.; LAVERSE, J.; FALCONE, P.M.; DEL NOBILE, M.A. Quality of spaghetti in base amaranthus wholemeal flour added with quinoa, broad bean and chick pea. Journal of Food Engineering, v.84, p. 101-107, 2008b.

9 HAARD, N.F. Características de los tejidos vegetales comestibles. In: FENNEMA, O. R. (Ed.). Química de los alimentos. Zaragoza: Acribia, 1992. p. 966-967.

10 HOSENEY, R.C. Principios de ciencia y tecnología de los cereales. Zaragoza: Acribia 1991

11 ICC. International Association for Cereal Chemistry. Standard method n. 104/01: method for determination of ash in cereals and cereal products. Vienna, Austria, 1990.

12 INDRANI, D.; RAO, G.V. Rheological characteristics of wheat flour dough as influenced by ingredients of Parotta. Journal of Food Engineering, v.17, p. 110-105, 2007.

13 KNUCKLES, B.E.; HUDSON, C.A.; CHIU, M.M.; SAYRE, R.N. Effect of $\beta$-glucan barley fractions in high fiber bread and pasta. Cereal Foods World, v.42, p. 94-99, 1997

14 MARCONI, E.; CARCEA, M. Pasta from non traditional raw materials. Cereal Foods World, v.46, p. 522-529, 2001.

15 MINOLTA CO. Chroma meter CR300: instruction manual. Osaka, 1991.

16 MORAES, M.A.C. Métodos para avaliação sensorial dos alimentos. Campinas: Editora da UNICAMP, 1993.

17 PAUCAR-MENACHO, L.M.; SILVA, L,H.; BARRETTO, P.A.A.; MAZAL, G.; FAKHOURI, F.M.; STEEL, C.J.; COLLARESQUEIROZ, F.P. Desenvolvimento de massa alimentícia fresca funcional com a adição de isolado protéico de soja e polidextrose utilizando páprica como corante. Ciência e Tecnologia de Alimentos, v.28, p. 767-778, 2008.

18 PERESSINI, D.; SENSIDONI, A. Effect of soluble dietary fibre addition on rheological and breadmaking properties of wheat doughs. Journal of Cereal Science, v.49, p. 190-201, 2009.

19 ROSTAGNO, M.A.; PALMA, M.; BARROSO, C.G. Short-term stability of soy isoflavones extracts: sample conservation aspects. Food Chemistry, v.93, p. 557-564, 2005.

20 SCHEPPACH, W.; LUEHRS, H.; MELCHER, R.; GOSTNER, A.; SCHAUBER, J.; KUDLICH, T.; WEILER, F.; MENZEL, T. Antiinflammatory and anticarcinogenic effects of dietary fibre. Clinical Nutrition Supplements, v.1, p.51-58, 2004. 
21 SEIBEL, N.F.; BELEIA, A.D.P. Carboidratos das fibras de cotilédones e proteínas de produtos derivados de soja (Glycinemax (L.) Merril). Ciência e Tecnologia de Alimentos, v. 28, p. 607-613, 2008.

22 TOLEDO SCALE INDUSTRY OF BRAZIL LTDA. The user manual OHAUS model MB200. New Jersey, 1995.

23 WANG, M.; HAMER, R.J.; VAN VLIET, T.; GRUPPEN, H.; MARSEILLE, H.; WEEGELS, P.L. Effect of water unextractable solids on gluten formation and properties: mechanistic considerations. Journal of Cereal Science, v.37, p.55-64, 2003.

24 ZAIDEL, D.N.A.; CHIN, N.L.; RAHMAN, R.A.; KARIM, R. Rheological characterization of gluten from extensibility measurement. Journal of Food Engineering, v.86, p.549-556, 2008. 